\title{
Phenotypic and molecular characterization of a Brucella strain isolated from a minke whale (Balaenoptera acutorostrata)
}

\author{
Chantal Clavareau, ${ }^{1}$ Vincent Wellemans, ${ }^{1}$ Karl Walravens, ${ }^{1}$ \\ Morten Tryland, ${ }^{2}$ Jean-Michel Verger, ${ }^{3}$ Maggy Grayon, ${ }^{3}$ Axel Cloeckaert, ${ }^{3}$ \\ Jean-Jacques Letesson ${ }^{4}$ and Jacques Godfroid ${ }^{1}$
}

Author for correspondence: Jacques Godfroid. Tel: +32 237544 55. Fax: +32 23750979 .

e-mail: jagod@var.fgov.be

1 Centre d'Etude et de Recherches Vétérinaires et Agrochimiques, 99 Groeselenberg, B-1180 Brussels, Belgium

2 Norwegian College of Veterinary Medicine, Department of Arctic Veterinary Medicine, N-9005 Tromsø, Norway

3 Institut National de la Recherche Agronomique, Laboratoire de Pathologie Infectieuse et Immunologie, F-37380 Nouzilly, France

4 Facultés Universitaires Notre-Dame de la Paix, Unité d'ImmunologieMicrobiologie, B-5000 Namur, Belgium

\begin{abstract}
Isolation of Brucella spp. in marine mammals has been reported during the past several years. A Brucella strain from the spleen and liver of a minke whale (Balaenoptera acutorostrata) was isolated. Conventional typing methods indicated that this isolate was related to the genus Brucella but did not match the profiles of any known Brucella species or biovar. Successful PCR amplification of the Brucella rrs-rrl spacer sequence and of the insertion sequence IS6501 also indicated that the minke whale strain was related to the genus Brucella. In addition, the rrs gene of this strain shared a very high degree of nucleotide identity ( $>98 \%$ ) with published Brucella spp. rrs sequences. However, RFLP studies using an IS6501-specific probe showed a unique profile for this strain in comparison with the profiles of the six known Brucella species. Moreover, analysis of the omp2 locus by PCR-RFLP, by Southern hybridization using omp2a- and omp2b-specific probes, and by DNA sequencing showed that the minke whale isolate possesses two copies of the omp $2 b$ gene instead of one omp2a and one omp2b gene copy or two copies of the omp2a gene described in the six known Brucella species. Thus, molecular typing methods showed that this isolate is clearly distinct from all other known Brucella species and strains. The specific molecular features of this minke whale Brucella isolate raise questions about the lineage between the Brucella strains isolated from marine mammals and the Brucella species isolated from terrestrial mammals.
\end{abstract}

Keywords: Brucella sp., brucellosis, minke whale (Balaenoptera acutorostrata)

\section{INTRODUCTION}

Brucellae are Gram-negative, facultative intracellular bacteria that can infect many species of animals and man (for review, see Young, 1995). Six species have been described within the genus Brucella: Brucella abortus, Brucella melitensis, Brucella suis, Brucella ovis, Brucella canis and Brucella neotomae (Corbel \& BrinleyMorgan, 1984). This classification is based mainly on differences in pathogenicity and host preference. The main pathogenic species worldwide are $B$. abortus,

Abbreviation: OMP, outer-membrane protein.

The GenBank accession numbers for the sequences reported in this paper are AF027600 (rrs) and AF027601 (omp2). responsible for bovine brucellosis, $B$. melitensis, the main aetiologic agent of ovine and caprine brucellosis, and $B$. suis, responsible for swine brucellosis. These three Brucella species may cause abortion in their hosts resulting in huge economic losses. B. ovis and B. canis cause ovine epididymitis and canine brucellosis, respectively. As for $B$. neotomae, only strains isolated from desert rats have been reported. Moreover, Brucella strains are often isolated from a great variety of wildlife species such as bison (Lawler, 1997), elk (Jensen et al., 1996), feral swine (Drew et al., 1992), wild boar (Godfroid et al., 1994), hare (Kautzsch et al., 1995), African buffalo (Waghela \& Karstad, 1986) and caribou (Ferguson, 1997).

The broad spectrum of Brucella hosts has recently been enlarged to include sea mammals. A number of recent 
reports have described the isolation and characterization of Brucella strains from a wide variety of sea mammals, including the bottlenose dolphin (Tursiops truncatus) (Ewalt et al., 1994), common seal (Phoca vitulina), harbour porpoise (Phocoena phocoena), common dolphin (Delphinus delphis) (Ross et al., 1994, 1996), Atlantic white-sided dolphin (Lagenorbynchus acutus), striped dolphins (Stenella coeruleoalba), hooded seal (Cystophora cristata), grey seal (Halichoerus grypus) and European otter (Lutra lutra) (Foster et al., 1996). Although the general characteristics of these isolates have been analysed by conventional typing methods, their profiles could not be assigned to any of the six Brucella species listed above. Brucella species and their different biovars are currently distinguished by differential tests based on serotyping, phage typing, dye sensitivity, $\mathrm{CO}_{2}$ requirement, $\mathrm{H}_{2} \mathrm{~S}$ production and metabolic properties (Alton et al., 1988; Verger \& Grayon, 1977).

Because the brucellae share a high degree of DNA homology ( $>90 \%$ for all species), Brucella has been proposed as a monospecific genus (Verger et al., 1985, 1987). Several techniques have been employed to find DNA polymorphisms which would enable the molecular typing of Brucella species and their different biovars. The genes encoding the major outer-membrane proteins (OMPs), omp25, omp31, omp2a and omp2b, have been found to be particularly useful for this purpose because they exhibit sufficient polymorphism to allow differentiation between Brucella species and some of their biovars (Cloeckaert et al., 1995, 1996a ; Ficht et al., 1990, 1996; Vizcaino et al., 1997). An insertion sequence named IS6501 (Ouahrani et al., 1993) or IS711 (Halling et al., 1993) has also been found to be useful for discriminating Brucella strains at the species or strain level (Ouahrani et al., 1993). The number of IS6501 copies in chromosomal DNA varies from 5 to 35 , depending on the Brucella species, and can be visualized by hybridization of an IS6501 probe to EcoRI-digested total DNA (Ouahrani et al., 1993). Other molecular techniques have been designed for the specific detection of Brucella species which are based on the PCR amplification of the $r r s-r r l$ ribosomal spacer DNA (Rijpens et al., 1996) and of IS6501 DNA using specific primers (S. Henault \& B. Garin-Bastuji, personal communication).

In November 1996, we isolated a Brucella strain for the first time from the spleen and the liver of a minke whale (Balaenoptera acutorostrata) that had been caught during commercial whaling off the Norwegian coast of Finnmark in May 1995. The purpose of the present study was to characterize this new isolate by conventional typing methods and by the molecular methods cited above.

\section{METHODS}

Bacterial strains and growth conditions. The minke whale (B202R) isolate was compared with FAO/WHO Brucella reference strains (Alton et al., 1988). The Brucella strains were grown on Brucella agar (Difco) supplemented with $5 \%$ horse serum (Gibco) at $37^{\circ} \mathrm{C}$ for $96 \mathrm{~h}$.

Conventional typing methods. The tests were performed according to the techniques described by Alton et al. (1988): culture on Brucella agar supplemented with $5 \%$ horse serum (Gibco) in the presence of basic fuchsin $\left(20 \mu \mathrm{g} \mathrm{ml}^{-1}\right)$, thionin $\left(10,20\right.$ or $\left.40 \mu \mathrm{g} \mathrm{ml}^{-1}\right)$ and safranin $\mathrm{O}\left(100 \mu \mathrm{g} \mathrm{ml}^{-1}\right)$. Urease and catalase activity, $\mathrm{H}_{2} \mathrm{~S}$ production, $\mathrm{CO}_{2}$ and serum requirement were evaluated. Serotyping was determined by agglutination tests using $\mathrm{A}$ - and $\mathrm{M}$-monospecific antisera (Wellcome). The strain was also tested for its susceptibility to $\mathrm{Tb}, \mathrm{Wb}, \mathrm{Iz}$ and $\mathrm{R} / \mathrm{C}$ brucellaphages. Oxidative metabolic tests were performed as described by Alton et al. (1988) and Verger \& Grayon (1977).

DNA preparation, PCR primers, probes and amplification conditions. DNA was prepared as described by Ausubel et al. (1990). PCR amplification of chromosomal DNA from the B202R isolate was performed with several sets of primers specific for Brucella spp.: one was specific for the $r r s$-rrl spacer rDNA (Rijpens et al., 1996) and another for IS6501 (S. Henault \& B. Garin-Bastuji, personal communication) (Table 1). Amplification reactions were prepared in $100 \mu \mathrm{l}$ volumes containing $10 \mathrm{mM}$ Tris/ $\mathrm{HCl}(\mathrm{pH} 7.4), 1.5 \mathrm{mM} \mathrm{MgCl}_{2}, 50 \mathrm{mM}$ $\mathrm{KCl}, 0 \cdot 1 \%$ Triton $\mathrm{X}-100,200 \mu \mathrm{M}$ dNTPs, $1 \mu \mathrm{M}$ primer, 100 ng genomic DNA and 2 U Dynazyme II DNA polymerase (Finnzymes). PCR amplifications were performed in a Techne PHC-3 thermocycler (New Brunswick). The amplification conditions were the same as those described in the references in Table 1.

RFLP and IS6501 hybridization. The IS6501 biotinylated probe was generated by random octamer priming of the PCR product with the NEBlot Phototope Kit (New England Biolabs). Genomic DNA was treated for $3 \mathrm{~h}$ with $40 \mathrm{U}$ EcoRI (Boehringer Mannheim) at $37^{\circ} \mathrm{C}$ before electrophoresis through a $0.8 \%$ agarose gel for $20 \mathrm{~h}$ at $25 \mathrm{~V}$. The DNA was then transferred to a nylon membrane (Biodyne A, Pall). The membrane-bound DNA was hybridized at $68^{\circ} \mathrm{C}$ with the biotinylated probe (IS6501) and then washed as described in the Phototope"-Star Detection Kit manual (New England Biolabs). Hybridized IS6501 probe was detected using the Phototope ${ }^{*}$-Star Detection Kit and by exposure of the hybridized membrane to an X-ray film (Kodak Scientific Imaging Film).

omp2a and omp2b hybridization. One microlitre of PCR product was blotted onto a nylon membrane (Biodyne A, Pall). After denaturation and neutralization, the DNA was fixed by UV exposure. Membrane-bound DNA was hybridized at $55^{\circ} \mathrm{C}$ with the biotinylated probe (Table 1). The membrane was washed twice with $6 \times \mathrm{SSC} / 0 \cdot 1 \%$ SDS at $55^{\circ} \mathrm{C}$ for $10 \mathrm{~min}$, once with $4 \times \mathrm{SSC} / 0.1 \%$ SDS at $55^{\circ} \mathrm{C}$ for $5 \mathrm{~min}$ and then once with $4 \times \mathrm{SSC} / 0.1 \% \mathrm{SDS}$ at $60^{\circ} \mathrm{C}$ for $5 \mathrm{~min}(1 \times \mathrm{SSC}$ is $0.15 \mathrm{M}$ sodium chloride $/ 0.015 \mathrm{M}$ sodium citrate). Biotinylated DNA was detected by using the Phototope ${ }^{*}$-Star Detection Kit.

PCR-RFLP of the major OMP genes. The major OMP genes, $o m p 25$, omp31, omp2a and omp2b, were characterized for polymorphism by PCR-RFLP as described previously (Cloeckaert et al., 1995; Vizcaino et al., 1997). Primers used are shown in Table 1.

rrs rDNA and omp2 locus DNA sequencing and omp2 phylogenetic analysis. DNA sequences were obtained by the dideoxy-chain termination method of Sanger et al. (1977). The DNAs used as sequencing templates were PCR products purified with Centricon-100 columns (Amicon). Sequencing 
Table 1. Nucleotide sequences of primers and probes used

The primers and probes were obtained from Biosource Europe (Belgium).

\begin{tabular}{|c|c|c|}
\hline Primer and probe & Sequence $\left(5^{\prime}-3^{\prime}\right)$ & Target DNA \\
\hline $\mathrm{rP} 2$ & ACGGCTACCTTGTTACGACTT & 16S DNA (Weisburg et al., 1991) \\
\hline fD1 & AGAGTTTGATCCTGGCTCAG & 16S DNA (Weisburg et al., 1991) \\
\hline $16 \mathrm{~S}-677$ & GCGTCAGTAATGGTCCAGTG & 16S DNA \\
\hline $16 S-1071$ & AGAGTGCCCAACTGAATGCTG & $16 \mathrm{~S}$ DNA \\
\hline Ba148-167F & TGCTAATACCGTATGTGCTT & 16S DNA (Herman \& De Ridder, 1992) \\
\hline Ba928-948 & TAACCGCGACCGGGATGTCAA & $16 S$ DNA (Herman \& De Ridder, 1992) \\
\hline P5 & TCGAGAATTGGAAAGAGGTC & 16S-23S rRNA spacer (Rijpens et al., 1996) \\
\hline P8 & GCATAATGCGGCTTTAAGA & 16S-23S rRNA spacer (Rijpens et al., 1996) \\
\hline $2 \mathrm{bC}$ & AATATGCGCCCTGCAGCCATAC & omp2 locus \\
\hline $2 b G$ & CCGAATTGTTCGCAGCATAG & omp2 locus \\
\hline $2 \mathrm{aE}$ & GTTTCCACCGGTTCGGAAAC & omp2 locus \\
\hline $2 \mathrm{bH}$ & TAAGCGTCGCAAACGCGGAC & omp2 locus \\
\hline 2IG1 & CCGAAGCGCTCCTTCTTCTG & omp2 locus \\
\hline 2IG2 & TCGCCTGCCGAATAAAGCCG & omp2 locus \\
\hline $2 \mathrm{IG} 3$ & AGCCAAGGAGAAGGCTCTTG & omp2 locus \\
\hline $2 \mathrm{aF}$ & TGACCGTAGTTCTGGTTCGG & omp2 locus \\
\hline $2 \mathrm{aA}$ & GGCTATTCAAAATTCTGGCG & omp2 locus (Cloeckaert et al., 1995) \\
\hline $2 \mathrm{aB}$ & ATCGATTCTCACGCTTTCGT & omp2 locus (Cloeckaert et al., 1995) \\
\hline $2 \mathrm{bA}$ & CCTTCAGCCAAATCAGAATG & omp2 locus (Cloeckaert et al., 1995) \\
\hline $2 \mathrm{bB}$ & GGTCAGCATAAAAAGCAAGC & omp2 locus (Cloeckaert et al., 1995) \\
\hline promomp $2 b$ & GCCACCTTGCCGACATATTCCGTT & omp2 locus \\
\hline IS6501A & ACGCCGGTGTATGGGAAAGGCTTTT & IS6501 \\
\hline IS6501B & GATAGAAGGCTTGAAGCTTGCGGAC & IS6501 \\
\hline omp2a probe & GGGTGGCGAAGACGTTGACAACGA & omp2a (Ficht et al., 1990) \\
\hline omp $2 b$ probe & GCGGCACCGTCATGGAGTTCGCG & omp2b (Ficht et al., 1990) \\
\hline
\end{tabular}

reactions were performed according to the manufacturer's instructions using the ABI PRISM Dye Terminator Cycle Sequencing Ready Reaction Kit (Perkin Elmer). A phylogenetic tree was derived from clustal w (http://www2. ebi.ac.uk/clustalw/) (Higgins et al., 1994) alignment of omp2a and $o m p 2 b$ sequences available in GenBank using the NJplot program (http://pbil.univ-lyon1.fr/software/njplot.html) (Perrière \& Gouy, 1996).

\section{RESULTS}

The isolate from minke whale is related to the genus Brucella as suggested by conventional typing

Gram staining of the B202R strain isolated from the spleen of the minke whale revealed small, Gram-negative coccobacilli (not shown). The strain grew on Brucella agar supplemented with $5 \%$ horse serum in the presence of basic fuchsin or thionin but did not grow in the presence of safranin $\mathrm{O} . \mathrm{CO}_{2}$ was not required for growth and $\mathrm{H}_{2} \mathrm{~S}$ was not produced. The isolate showed catalase, oxidase and urease activity. At the routine test dilution (RTD), the strain was lysed by the brucellaphages $\mathrm{Wb}$ and $\mathrm{Iz}$, but not by $\mathrm{Tb}$ and $\mathrm{R} / \mathrm{C}$. The strain was lysed by $\mathrm{Tb}$ at an RTD of $10^{4}$. Serotyping showed that the strain was A-dominant. The oxidative metabolic profile of strain B202R did not resemble the profiles of any of the known Brucella species and biovars (data not shown) (Alton et al., 1988; Verger \& Grayon,
1977). Thus, conventional typing methods suggested that the isolate was related to the genus Brucella but did not match the profiles of any established species or biovar.

\section{The isolate from minke whale belongs to the genus Brucella according to molecular detection methods}

For each set of primers specific for the rrs-rrl spacer rDNA (Rijpens et al., 1996) and for IS6501 (S. Henault $\&$ B. Garin-Bastuji, personal communication), an amplification product was obtained of the expected size, suggesting that the isolate belongs to the genus Brucella.

The nucleotide sequence of part of the rrs rDNA of strain B202R was determined. A homology search using BLAST (Altschul et al., 1990) showed the highest identity (>99.5\%) with rrs rDNA of the six Brucella species, thus indicating that this strain probably belongs to the genus Brucella.

\section{The isolate from minke whale cannot be classified within the known species of Brucella according to molecular typing methods}

(i) RFLP and IS6501 hybridization Fig. 1. shows IS6501 hybridized to EcoRI-digested total DNA RFLP patterns of strain B202R compared with Brucella reference 


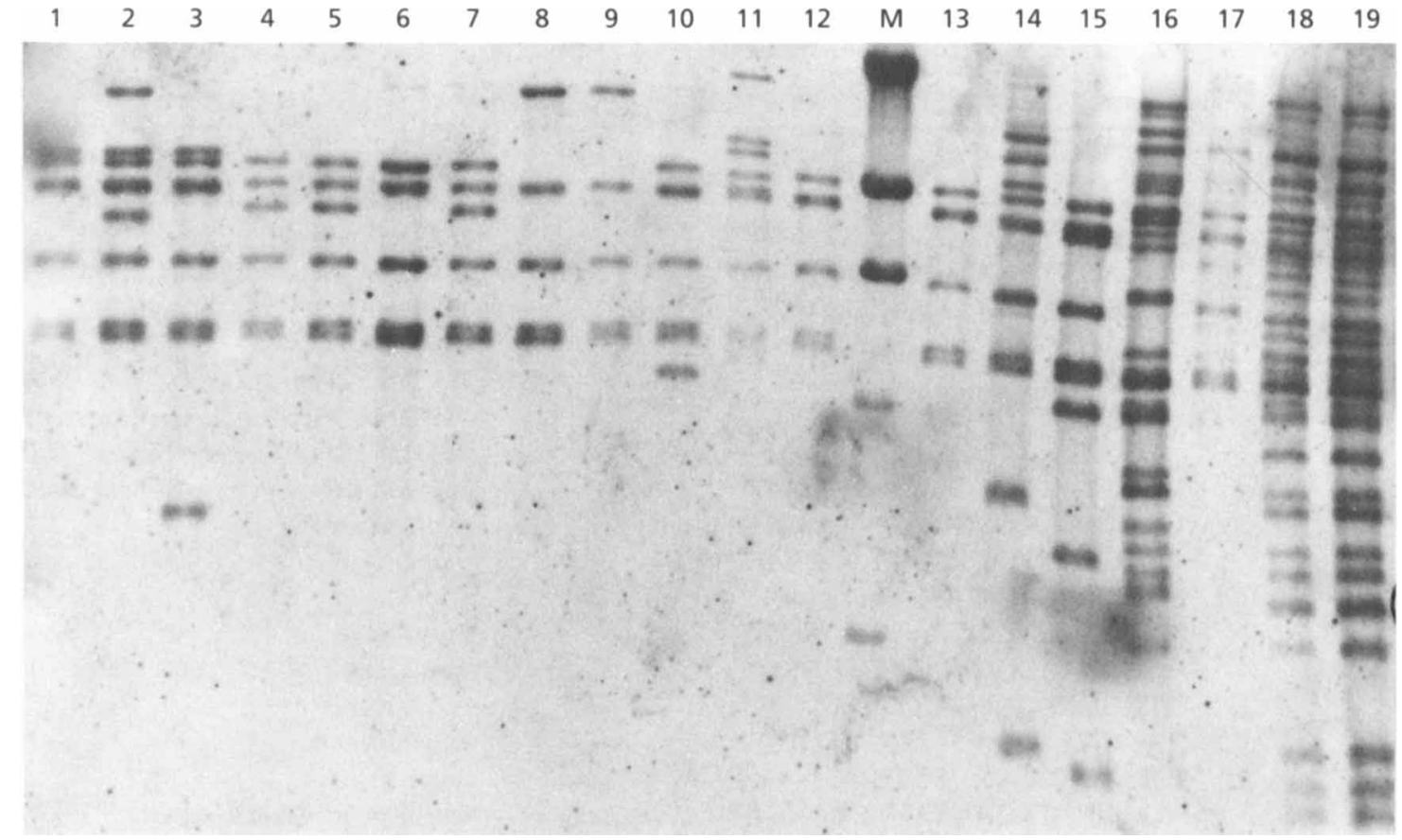

Fig. 1. IS6501 RFLP. Southern blot of EcoRI-digested DNA from Brucella reference strains and B202R strain probed with IS6501. Lanes: 1, B. melitensis bv1; 2, B. melitensis bv2; 3, B. melitensis bv3; 4, B. abortus bv1; 5, B. abortus bv2; 6 , B. abortus bv3; 7, B. abortus bv4; $8, B$. abortus bv6; 9 , B. abortus bv9; $10, B$. suis bv1; 11 , $B$. suis bv2; 12 , B. suis bv3; $13, B$. suis bv4; 14 , B. suis bv5; 15 , B. neotomae; $16, B$. ovis; $17, B$. canis; $18-19, B 202 R ; M$, molecular mass marker ( $\lambda$ Hindlli).

strains. More than 25 IS6501 bands appeared in the restricted DNA of strain B202R, which is close in number to $B$. ovis and much higher than the number of bands occurring in the other reference strains. Nevertheless, the pattern of strain B202R was very different from the Brucella type strains, including $B$. ovis.

(ii) omp25 and omp31 PCR-RFLP Species-specific markers on omp25 and omp31 have been identified previously for B. melitensis (absence of the EcoRV site in omp25), $B$. ovis (short deletion in omp25), B. abortus (absence of the omp31 gene) and B. canis (specific AvalI restriction pattern of omp31) (Cloeckaert et al., 1995, 1996a,b; Vizcaino et al., 1997). The omp25 and omp31 genes were successfully amplified from the DNA of strain B202R, indicating again that it is probably a member of the Brucella genus (data not shown). None of the species-specific markers cited above were detected for strain B202R (data not shown) and no additional polymorphism was detected with the restriction enzymes used for omp25 and omp31 PCR-RFLP. Thus, it appeared that strain B202R could not be classified within the B. abortus, B. melitensis, B. ovis or B. canis species.

(iii) The isolate from minke whale possesses two copies of omp2b Two closely related genes, omp2a and omp $2 b$, located in the Brucella omp2 locus, encode and potentially express the $36 \mathrm{kDa}$ porin OMP (Ficht et al., 1989). The genes share about $85 \%$ DNA homology. They are separated by $900 \mathrm{bp}$ and are oriented in opposite directions. The gene arrangement at the $o m p 2$ locus appears to be conserved in all Brucella species (Ficht et al., 1990). However, B. ovis has two genes closely related to $\operatorname{omp} 2 a$ instead of the one copy of omp $2 a$ and one copy of omp $2 b$ detected in the other Brucella species (Ficht et al., 1990). These genes are of particular interest because biovar-specific markers for $B$. suis biovars and species-specific markers for $B$. neotomae have been identified (Cloeckaert et al., 1995).

PCR-RFLP of the $o m p 2 a$ and $o m p 2 b$ genes successfully amplified from the DNA of strain B202R showed some unexpected results. In particular, restrictions performed with most enzymes on its amplified omp $2 a$ gene showed restriction patterns that were different from previously characterized omp $2 a$ genes. In fact, restriction patterns with most of the restriction enzymes of the B202R strain omp $2 a$ gene appeared to be almost identical to those of its omp $2 b$ gene (Fig. 2). This observation suggests that strain $\mathrm{B} 202 \mathrm{R}$ carries two omp $2 b$ gene copies which is a characteristic that has not yet been reported in strains of the six Brucella species.

Further hybridization of an $o m p 2 b$-specific probe to both the amplified omp $2 a$ and $o m p 2 b$ genes of strain B202R also suggested that this strain possesses two copies of omp2b (not shown).

The nucleotide sequence of the omp2 locus of strain B202R was determined from three overlapping PCR products and sequenced as described in Methods. The complete nucleotide sequence of this locus (3146 bp) 


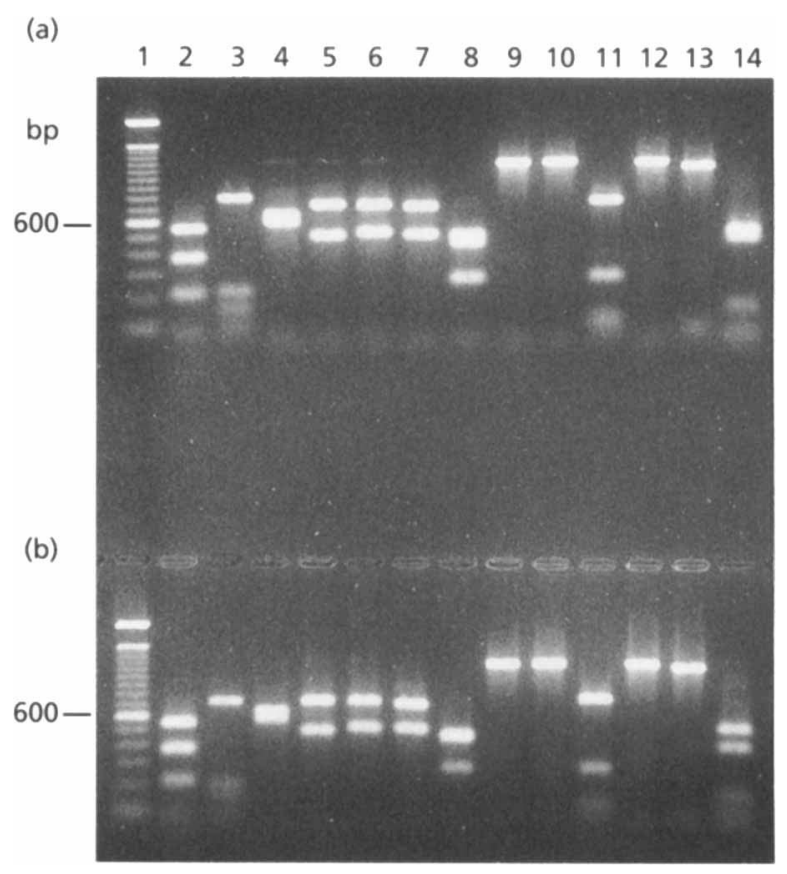

Fig. 2. Restriction patterns of $P C R$-amplified omp2b (a) and omp2a (b) genes of the minke whale isolate (B202R) cut by Alul (lanes 2), Banl (3), Bg/II (4), Clal (5), EcoRI (6), Haelll (7), Hinfl (8), Kpnl (9), Ncol (10), Pstl (11), Pvull (12), Styl (13) and Taql (14). Lanes 1: molecular mass marker (100 bp DNA ladder; Gibco).

was compared with those from the six known Brucella species. As seen in these species, the two omp2 genes of strain B202R were separated by $900 \mathrm{bp}$ and oriented in opposite directions. However, alignment of the two homologous regions (omp2a and omp2b) of strain B202R revealed that the two genes share about $98.9 \%$ identity (nucleotide differences at only five positions) without any insertion or deletion as seen in those from the other Brucella species. In addition, alignment of both genes with those of the other Brucella species showed that they had the highest identity levels with the omp $2 b$ gene of $B$. neotomae reference strain $5 \mathrm{~K} 33 \quad(96.9 \%$ identity). This is also illustrated in the phylogenetic tree in Fig. 3 derived from ClUSTAL $w$-aligned omp $2 a$ and $o m p 2 b$ nucleotide sequences. Thus, the nucleotide sequence determined from the omp2 locus of strain $\mathrm{B} 202 \mathrm{R}$ confirmed the presence of two omp $2 b$ gene copies which were nearly identical to the omp $2 b$ gene of B. neotomae.

\section{DISCUSSION}

In this paper we describe a Brucella strain (B202R) isolated for the first time from a minke whale. Colony morphology, Gram staining, biochemical tests, phagetyping and serotyping indicated that strain B202R belongs to the Brucella genus. However, biotyping and the oxidative profile showed that this strain has unique characteristics in comparison with those of the six known species.
The specific PCR amplification of a portion of IS6501 as well as the $r r s-r r l$ rDNA spacer and the $r r s$ rDNA nucleotide sequence determination confirm the results of the conventional typing methods. In addition, the omp 25 and $o m p 31$ genes were successfully PCR-amplified but did not reveal any species-specific markers identified for four Brucella species and did not show additional polymorphism allowing classification of strain B202R. The omp2 locus of strain B202R had the same general organization as the other Brucella species, i.e. the presence of two omp2 genes separated by $900 \mathrm{bp}$ and oriented in opposite directions. However, in contrast to the six known Brucella species (Ficht et al., 1990), strain B202R appeared to have two copies of the omp2b gene as shown by PCR-RFLP, hybridization with an $o m p 2 b$ specific probe and by determining the nucleotide sequence of the omp2 locus. The identity of both omp $2 b$ genes of strain $\mathrm{B} 202 \mathrm{R}$ reached $96.9 \%$ with the omp $2 b$ gene of $B$. neotomae $5 \mathrm{~K} 33$.

On the basis of polymorphism at the omp2 locus, $B$. neotomae and B. ovis are the most divergent taxa of the Brucella species (Ficht et al., 1996). The extreme divergence of $B$. ovis (presence of two omp2a gene copies) from the other Brucella species has been shown to be due to a lack of divergence between its omp2a and omp $2 b$ gene sequences. Indeed, the genes in $B$. ovis differ by only $30 \mathrm{nt}$ at their $3^{\prime}$ ends. In B. abortus, B. melitensis, $B$. suis and $B$. canis a mean of $130 \mathrm{nt}$ differences are observed in the two gene copies (at the $3^{\prime}$ ends). The genes in B. neotomae differ at only 112 positions. At the other 28 positions (all at the $3^{\prime}$ end) the sequences are identical and correspond to the profile obtained for omp2a. It was therefore suggested that either the progenitor gene closely resembled omp $2 a$ or gene conversion corrected the $5^{\prime}$ end of the omp $2 b$ gene in $B$. ovis by using omp2a as the template (Ficht $e$ t al., 1996). As shown in the present study, the occurrence of Brucella strains such as the one isolated from the minke whale carrying two omp $2 b$ gene copies contrasts with the hypothesis of a progenitor species with two omp $2 a$ genes. In addition, the very high identity between the two omp2b gene copies in strain B202R with no deletion or addition would suggest a recent duplication of the gene and/or perhaps a much slower evolution of marine brucellae.

RFLP and IS6501 hybridization also demonstrated a profile for strain $\mathrm{B} 202 \mathrm{R}$ distinct from the profiles of the Brucella type strains. Thus, IS6501 RFLP up to now has shown two groups of patterns: one has a low number of bands $(<10 ; B$. melitensis, B. suis, B. neotomae, $B$. abortus, $B$. canis) and the other has a high number of bands $(>25 ; B$. ovis and strain B202R). However, within the second group, the two profiles were clearly different, suggesting that strain B202R could be phylogenetically more distant from the other Brucella species.

Thus, the most significant observations in this present study were (i) isolation of a Brucella strain from a minke whale which has some phenotypic characteristics that differ from type strains of the six known Brucella species and their biovars and (ii) the presence in this strain of 


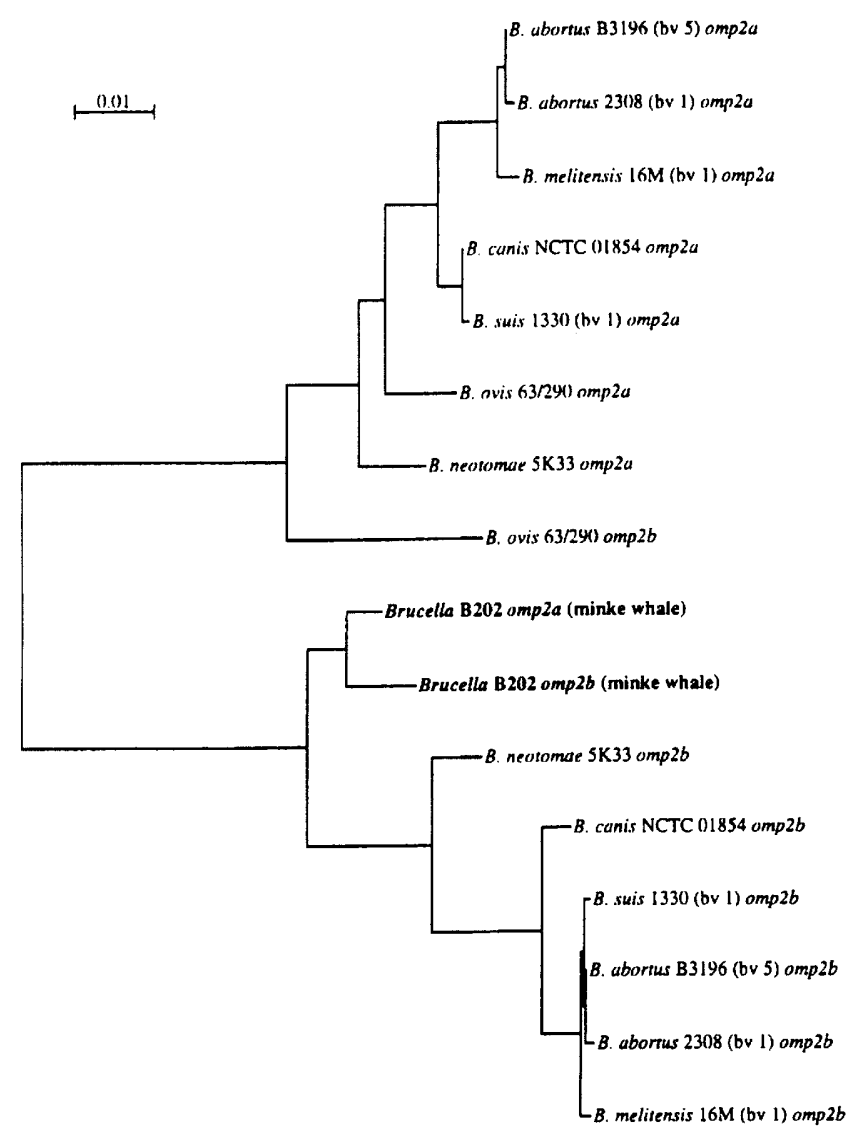

Fig. 3. Phylogenetic tree derived from CLUSTAL W-aligned omp2a and $o m p 2 b$ nucleotide sequences. The figure clearly shows that the omp2a and omp2b nucleotide sequences from the minke whale isolate are closely related and belong to the omp $2 b$ group of genes.

two omp $2 b$ gene copies and an IS6501 RFLP pattern which is clearly distinct from other Brucella strains, making the isolate genetically more distant from the six known Brucella species. Molecular characterization of other isolates from marine mammals is now required to determine if these features are specific to marine brucellae.

\section{ACKNOWLEDGEMENTS}

C. Clavareau and V. Wellemans contributed equally to this work. We thank H. Cassiman and P. Michel for culture and control of bacterial strains; $H$. Vanderhallen for assistance with DNA sequence determination and analyses. We also thank P. Flanagan for correcting and improving our English.

\section{REFERENCES}

Alton, G. G., Jones, L. M., Angus, R. D. \& Verger, J. M. (1988). Techniques for the Brucellosis Laboratory. Paris: Institut National de la Recherche Agronomique.

Altschul, S. F., Gish, W., Miller, W., Myers, E. W. \& Lipman, D. J. (1990). Basic local alignment search tool. J Mol Biol 215, 403-410.
Ausubel, F. M., Brent, R., Kingston, R. E., Moore, D. D., Seidman, J. G., Smith, J. A. \& Struhl, K. (1990). Current Protocols in Molecular Biology. New York: Wiley.

Cloeckaert, A., Verger, J. M., Grayon, M. \& Grépinet, O. (1995). Restriction site polymorphism of the genes encoding the major $25 \mathrm{kDa}$ and $36 \mathrm{kDa}$ outer-membrane proteins of Brucella. Microbiology 141, 2111-2121.

Cloeckaert, A., Verger, J. M., Grayon, M. \& Vizcaino, N. (1996a). Molecular and immunological characterization of the major outer membrane proteins of Brucella. FEMS Microbiol Lett 145, 1-8.

Cloeckaert, A., Verger, J. M., Grayon, M., Zygmunt, M. S. \& Grépinet, O. (1996b). Nucleotide sequence and expression of the gene encoding the major 25-kilodalton outer membrane protein of Brucella ovis: evidence for antigenic shift, compared with other Brucella species, due to a deletion in the gene. Infect Immun 64, 2047-2055.

Corbel, M. J. \& Brinley-Morgan, W. J. (1984). Genus Brucella Meyer and Shaw 1920.173 ${ }^{\mathrm{AL}}$. In Bergey's Manual of Systematic Bacteriology, vol. 1, pp. 377-388. Edited by N. R. Krieg \& J. G. Holt. Baltimore: Williams \& Wilkins.

Drew, M. L., Jessup, D. A., Burr, A. A. \& Franti, C. E. (1992). Serologic survey for brucellosis in feral swine, wild ruminants, and black bear of California, 1977 to 1989. J Wildl Dis 28, 355-363.

Ewalt, D. R., Payeur, J. B., Martin, B. M., Cummins, D. R. \& Miller, W. G. (1994). Characteristics of a Brucella species from a bottlenose dolphin (Tursiops truncatus). J Vet Diagn Invest $\mathbf{6}$, 448-452.

Ferguson, M. A. (1997). Rangiferine brucellosis on Baffin island. $J$ Wildl Dis 33, 536-543.

Ficht, T. A., Bearden, S. W., Sowa, B. A. \& Adams, L. G. (1989). DNA sequence and expression of the 36-kilodalton outer membrane protein gene of Brucella abortus. Infect Immun 57, 3281-3291.

Ficht, T. A., Bearden, S. W., Sowa, B. A. \& Marquis, H. (1990). Genetic variation of the omp2 porin locus of the brucellae: species-specific markers. Mol Microbiol 4, 1135-1142.

Ficht, T. A., Husseinen, H. S., Derr, J. \& Bearden, S. W. (1996). Species-specific sequences at the omp2 locus of Brucella type strains. Int J Syst Bacteriol 46, 329-331.

Foster, G., Jahans, K. L., Reid, R. J. \& Ross, H. M. (1996). Isolation of Brucella species from cetaceans, seals and an otter. Vet Rec 138, 583-585.

Godfroid, J., Michel, P., Uytterhaegen, L., De Smedt, C., Rasseneur, F., Boelaert, F., Saegerman, C. \& Patigny, X. (1994). Brucellose enzootique á Brucella suis biotype 2 chez le sanglier (Sus scrofa) en Belgique. Ann Méd Vét 138, 263-268.

Halling, S. M., Tatum, F. M. \& Bricker, B. J. (1993). Sequence and characterization of an insertion sequence, IS711, from Brucella ovis. Gene 133, 123-127.

Herman, L. \& De Ridder, H. (1992). Identification of Brucella spp. by using the polymerase chain reaction. Appl Env Microbiol 58, 2099-2101.

Higgins, D., Thompson, J., Gibson, T., Thompson, J. D., Higgins, D. G. \& Gibson, T. J. (1994). CLUSTAL W : improving the sensitivity of progressive multiple sequence alignment through sequence weighting, position-specific gap penalties and weight matrix choice. Nucleic Acids Res 22, 4673-4680.

Jensen, A. E., Ewalt, D. R., Cheville, N. F., Thoen, C. O. \& Payeur, J. B. (1996). Determination of stability of Brucella abortus RB51 by use of genomic fingerprint, oxidative metabolism, and colonial 
morphology and differentiation of strain RB51 from B. abortus isolates from bison and elk. J Clin Microbiol 34, 628-633.

Kautzsch, S., Seyfarth, D., Schone, R. \& Stehmann, R. (1995). An outbreak of brucellosis in pigs and conclusions derived on the epidemiology of this animal disease. Berl Muench Tieraerztl Wochenschr 108, 201-205.

Lawler, A. (1997). Bison study marks radical shift for research council. Science 276, 1786-1787.

Ouahrani, S., Michaux, S., Widada, J. S., Bourg, G., Tournebize, R., Ramuz, M. \& Liautard, J. P. (1993). Identification and sequence analysis of IS6501, an insertion sequence in Brucella spp.: relationship between genomic structure and the number of IS6501 copies. J Gen Microbiol 139, 3265-3273.

Perrière, G. \& Gouy, M. (1996). WWW-Query : An on-line retrieval system for biological sequence banks. Biochimie 78, 364-369.

Rijpens, N. P., Jannes, G., Van Asbroeck, M., Rossau, R. \& Herman, L. (1996). Direct detection of Brucella spp. in raw milk by PCR and reverse hybridization with 16S-23S rRNA spacer probes. Appl Env Microbiol 62, 1683-1688.

Ross, H. M., Jahans, K. L., MacMillan, A. P., Reid, R. J., Thompson, P. M. \& Foster, G. (1994). Brucella species infection in seamammals. Vet Rec 138, 359.

Ross, H. M., Jahans, K. L., MacMillan, A. P., Reid, R. J., Thompson, P. M. \& Foster, G. (1996). Brucella species infection in North Sea seal and cetacean populations. Vet Rec 138, 647-648.

Sanger, F., Nicklen, S. \& Coulson, A. R. (1977). DNA sequencing with chain-terminating inhibitors. Proc Natl Acad Sci USA 74, 5463-5467.

Verger, J. M. \& Grayon, M. (1977). Oxidative metabolic profiles of Brucella species. Ann Sclavo 19, 46-60.

Verger, J. M., Grimont, F., Grimont, P. A. D. \& Grayon, M. (1985). Brucella, a monospecific genus as shown by deoxyribonucleic acid hybridization. Int J Syst Bacteriol 35, 292-295.

Verger, J. M., Grimont, F., Grimont, P. A. D. \& Grayon, M. (1987). Taxonomy of the genus Brucella. Ann Inst Pasteur Microbiol 138, 235-238.

Vizcaino, N., Verger, J. M., Grayon, M., Zygmunt, M. S. \& Cloeckaert, A. (1997). DNA polymorphism at the omp-31 locus of Brucella spp.: evidence for a large deletion in Brucella abortus, and other species-specific markers. Microbiology 143, 2913-2921.

Waghela, S. \& Karstad, L. (1986). Antibodies to Brucella spp. among blue wildebeest and African buffalo in Kenya. J Wildl Dis 22, 189-192.

Weisburg, W. G., Barns, S. M., Pelletier, D. A. \& Lane, D. J. (1991). $16 S$ ribosomal DNA amplification for phylogenetic study. J Bacteriol 173, 697-703.

Young, E. J. (1995). An overview of human brucellosis. Clin Infect Dis 21, 283-290.

Received 14 April 1998; revised 25 August 1998; accepted 27 August 1998. 